\title{
PARENTING PLANS ATTENTIVE TO THE NEEDS OF THE DIVORCING FAMILY
}

\author{
Tanya Robinson \\ $B A$ MSD NEC DPhil PhD \\ COMPRES, North-West University, Potchefstroom \\ Elma Ryke \\ BA Post Grad Dipl. in Philosophy MA PhD \\ COMPRES, North-West University, Potchefstroom \\ Cornelia Wessels \\ BA MA PhD \\ COMPRES, North-West University, Potchefstroom
}

SUMMARY

Practical parenting plans should prioritise the needs of the divorcing family by giving voice to the feelings, needs and rights of the children while reflecting on the requests of the parents. If the needs of both parents and their children are not signified, parenting plans will be redundant, as families will not be able to implement parenting plans to structure their lives post-divorce and dysfunction will set in. Establishing the needs of the divorcing family is important when professionals structure a parenting plan as representative parenting plans will assist in managing post-divorce conflict dynamics. This article will present rich qualitative data to demonstrate the needs of the divorcing family and alert professionals to the importance of need representation in parenting plans.

\section{$1 \quad$ INTRODUCTION}

The title of this article speaks intentionally of the "divorcing family". The terminology emphasises that it is not only the parents that divorce and highlights the emotional trauma that the family unit undergoes during divorce. This article will thus not refer to "divorcing parents" but to the "divorcing family", so as to emphasise the effect of divorce on the family unit. Engelbrecht and Rencken-Wentzel ${ }^{1}$ explain that the organisation of family life and the division of responsibilities in the reconstructed family can be described in a document called a parenting plan while section 33(3) of the Children's Act ${ }^{2}$ explains that a parenting plan may determine any matter in connection with parental rights and responsibilities, including:

Engelbrecht and Rencken-Wentzel Divorce: A South African Guide (1999) 190. 38 of 2005. 
"(a) where and with whom the child is to live;

(b) the maintenance of the child;

(c) contact between the child and-

(i) any of the parties; and

(ii) any other person; and

(d) the schooling and religious upbringing of the child."

Section 7 of the Children's Act, ${ }^{3}$ Article 12 of the Convention on the Rights of the Child, ${ }^{4}$ and Articles 4 and 7 of the African Charter on the Rights and Welfare of the Child ${ }^{5}$ emphasise the best-interests-of-the-child standard and focus on protecting children's feelings, needs and rights. ${ }^{6}$ For that reason, parenting plans ought to be representative of the children's needs and meet their interests while representing the family's needs holistically. It is imperative that, throughout the process of preparing a parenting plan, the professional ask questions as to who, what and when, as this will give insight and clarity while structuring parenting plans for the divorcing family.

The article will present two aspects of compiling parenting plans: first, the needs of the divorcing family (including parents and children) during and after the divorce; and secondly, the inclusion of their needs in the structuring of parenting plans. A "need" is defined as a factor that is essential to living a healthy and purposeful life. ${ }^{8}$ The needs of the divorcing family, together with the standard of the best interests of the child, ought to be considered in drafting parenting plans. Parenting plans should not merely reflect textbook familiarity, and professional suggestions and recommendations, as this may lead to impractical and unrealistic parenting plans. A parenting plan should be a practical document that can be easily implemented and understood by family members - not a redundant document. ${ }^{9}$

Swerdlow-Freed ${ }^{10}$ explains that parents and children have individual needs that ought to be met after divorce. Often parents and children do not convey their needs to professionals during the process, and therefore the family's needs remain unrepresented. ${ }^{11}$ This article intends to provide professionals with insight into the needs of a divorcing family, and with

3 Ibid.

4 UN General Assembly Convention on the Rights of the Child (20 November 1989) United Nations Treaty Series vol 1577 p3.

5 Organization of African Unity (OAU) African Charter on the Rights and Welfare of the Child (11 July 1990) CAB/LEG/24.9/49 (1990).

6 De Jong "Australia's Family Relationship Centres: A Possible Solution to Creating an Accessible and Integrated Family Law System as Envisaged by the South African Law Reform Commission's Issue Paper 31 of 2015" 2017 TSAR 298299.

7 Meyer "How to Move On and Rebuild Your Life after Divorce" (2010) http://divorcesupport.about.com (accessed 2018-04-12) 10; Swerdlow-Freed "Essential Elements of Competent Child Custody Evaluations" (2010) http://expertpages.com/news/ child_custody_evaluation_elements.htm (accessed 2010-03-26) 1.

8 Macmillan Dictionary (2018) http://www.macmillandictionary.com (accessed 2018-06-14) 1.

9 Leisewitz "Parenting Plans: What They Are and Why They Are Helpful" 2016 Mental Health Matters 48.

10 Swerdlow-Freed http://expertpages.com/news/child_custody_evaluation_elements.htm 1.

11 DeMatteo, Marczyk, Krauss and Burl "Educational and Training Models in Forensic Psychology" 2009 3(3) Training and Education in Professional Psychology 184-191 http://dx.doi.org/10.1037/a0014582 1. 
guidance for parenting plans that capture the divorcing families' needs and serve the best interests of the children.

\section{METHOD}

The research design of the study followed an explorative research approach $^{12}$ and an instrumental case study ${ }^{13}$ to elaborate on theory (the best-interests-of-the-child standard) and to gain a better understanding of a social issue (the needs of the parents and children post-divorce). Furthermore, it used a document study to gather information from forensic social work assessment reports. The gatekeeper, Intercare Medical and Dental Centre in Fourways, Gauteng, gave its consent to conduct this study. Participants whose files were selected gave written permission for their files to form part of the research study. The forensic assessment reports contained information on parents' insights, psycho-emotional assessments of children, and facilitated observational sessions with children and parents. The documents were selected using a purposive sampling technique. ${ }^{14}$ The sampling size was set at a minimum of 20 files, and the criteria for inclusion ensured that the forensic assessment reports specifically focused on divorce mediation, divorcing families with children and the structuring of parenting plans.

Each file was studied to deduce information and organise data according to themes. Nine themes were identified. E-mail communication with the participants allowed the participants to give their interpretation of their case according to the nine identified themes. The aim was to obtain further insight into the families' respective needs and to verify the interpretation of their files. Parents provided feedback as to their own and their children's needs. The electronic communication with participants was used to add richness to the information and to verify the credibility of the file interpretations. A coprofessional was appointed to assist in studying the files, to confirm the data analysis process and to ensure valid interpretation of the data.

The data was managed by allocating a number to each selected file to ensure anonymity. Included in Table 1 is a profile of participants with information on the number of years a couple was married, the age of the biological mother and father, the number of children in the family, and the gender and age of the children.

\section{PROFILE OF PARTICIPANTS}

Table 1 contains information about the research participants.

Babbie The Practice of Social Research 14ed (2015) 281.

Creswell and Poth Qualitative Inquiry \& Research Design 4ed (2018) 115; Babbie The Practice of Social Research 281.

14 Strydom and Delport "Sampling and Pilot Study in Qualitative Research" in De Vos, Strydom, Fouche and Delport Research at Grass Roots: For the Social Sciences and Human Service Professions (2011) 329. 
Table 1: Profile of research participants

\begin{tabular}{|c|c|c|c|c|c|c|}
\hline Files & $\begin{array}{c}\text { Years } \\
\text { married }\end{array}$ & $\begin{array}{c}\text { Age of the } \\
\text { biological } \\
\text { mother }\end{array}$ & $\begin{array}{c}\text { Age of the } \\
\text { biological } \\
\text { father }\end{array}$ & $\begin{array}{l}\text { Number } \\
\text { of } \\
\text { children }\end{array}$ & $\begin{array}{l}\text { Gender } \\
\text { of the } \\
\text { children }\end{array}$ & $\begin{array}{c}\text { Age of } \\
\text { the } \\
\text { children }\end{array}$ \\
\hline File 1 & 10 & 40 & 42 & 2 & $\begin{array}{l}\text { Female } \\
\text { Female }\end{array}$ & $\begin{array}{l}4 \\
8\end{array}$ \\
\hline File 2 & 19 & 42 & 45 & 2 & $\begin{array}{c}\text { Female } \\
\text { Male }\end{array}$ & $\begin{array}{l}17 \\
15 \\
\end{array}$ \\
\hline File 3 & 11 & 35 & 38 & 2 & $\begin{array}{l}\text { Male } \\
\text { Male }\end{array}$ & $\begin{array}{l}6 \\
9\end{array}$ \\
\hline File 4 & 14 & 36 & 38 & 2 & $\begin{array}{c}\text { Female } \\
\text { Male }\end{array}$ & $\begin{array}{c}12 \\
8\end{array}$ \\
\hline File 5 & 6 & 34 & 36 & 1 & Male & 4 \\
\hline File 6 & 11 & 34 & 35 & 2 & $\begin{array}{l}\text { Male } \\
\text { Male }\end{array}$ & $\begin{array}{l}7 \\
9\end{array}$ \\
\hline File 7 & 14 & 37 & 38 & 1 & Female & 12 \\
\hline File 8 & 13 & 34 & 36 & 1 & Female & 11 \\
\hline File 9 & 8 & 42 & 59 & 1 & Male & 5 \\
\hline $\begin{array}{l}\text { File } \\
10\end{array}$ & 15 & 38 & 45 & 2 & $\begin{array}{c}\text { Female } \\
\text { Male }\end{array}$ & $\begin{array}{l}15 \\
10\end{array}$ \\
\hline $\begin{array}{l}\text { File } \\
11\end{array}$ & 8 & 30 & 36 & 2 & $\begin{array}{l}\text { Female } \\
\text { Female }\end{array}$ & $\begin{array}{l}5 \\
7\end{array}$ \\
\hline $\begin{array}{l}\text { File } \\
12\end{array}$ & 7 & 36 & 55 & 1 & Male & 5 \\
\hline $\begin{array}{l}\text { File } \\
13\end{array}$ & 7 & 27 & 36 & 2 & $\begin{array}{c}\text { Female } \\
\text { Male }\end{array}$ & $\begin{array}{l}2 \\
6\end{array}$ \\
\hline $\begin{array}{l}\text { File } \\
14\end{array}$ & 7 & 40 & 51 & 1 & Female & 4 \\
\hline $\begin{array}{l}\text { File } \\
15\end{array}$ & 15 & 40 & 36 & 1 & Female & 13 \\
\hline $\begin{array}{l}\text { File } \\
16\end{array}$ & 10 & 34 & 44 & 1 & Male & 8 \\
\hline $\begin{array}{l}\text { File } \\
17\end{array}$ & 8 & 32 & 35 & 2 & $\begin{array}{c}\text { Female } \\
\text { Male }\end{array}$ & $\begin{array}{l}6 \\
4\end{array}$ \\
\hline $\begin{array}{l}\text { File } \\
18\end{array}$ & 15 & 35 & 41 & 3 & $\begin{array}{c}\text { Female } \\
\text { Female } \\
\text { Male }\end{array}$ & $\begin{array}{c}13 \\
11 \\
9\end{array}$ \\
\hline $\begin{array}{l}\text { File } \\
19\end{array}$ & 12 & 32 & 35 & 2 & $\begin{array}{l}\text { Female } \\
\text { Female }\end{array}$ & $\begin{array}{c}8 \\
10 \\
\end{array}$ \\
\hline \multirow[t]{2}{*}{$\begin{array}{l}\text { File } \\
20\end{array}$} & 8 & 35 & 37 & 1 & Female & 5 \\
\hline & $X=10.9$ & $X=35.65$ & $X=40.9$ & $X=1.6$ & $\begin{array}{l}F=18 \\
(56 \%) \\
M=14 \\
(44 \%)\end{array}$ & $X=8,375$ \\
\hline
\end{tabular}

Table 1 allowed for detailed information about the research participants. The profile indicates that the couples were married to each other for an average 
of 10.9 years before they decided to divorce. The South African Divorce Rate ${ }^{15}$ indicates that irrespective of population group, most South African couples who divorced were married for five to nine years. $\mathrm{McCloud}^{16}$ ascribes the tendency for marriages to last ten years on average to the cyclical process of marriage. The sample in this study correlated to a fair degree with the findings in the literature.

The average age of the 20 biological mothers who formed part of the research study is 35.65 years. The South African Divorce Rate ${ }^{17}$ indicates that the median age at divorce in 2016 was 38 years for women. A 2.35 year age difference was found between that age and the age reported in this study. The average age of the 20 biological fathers who formed part of the research study was 40.9 years. The South African Divorce Rate ${ }^{18}$ indicates that the median age at divorce in 2016 was 41 for men. A relatively correlated age difference of 0.1 was found. It seems that couples are frequently in their middle life when they decide to file for a divorce. Situational factors influence the decision to divorce, and incompatibility appears to be more predictive of divorce in later life than individual personality factors - for example, neuroticism or disagreeableness. ${ }^{19}$

\section{$4 \quad$ RESULTS}

The nine identified themes extracted from the forensic files reflect the needs of children and parents.

Table 2: Themes reflecting the needs of the divorcing family

\begin{tabular}{|c|c|}
\hline $\begin{array}{l}\text { Needs of } \\
\text { children }\end{array}$ & $\begin{array}{l}\text { 1. To feel less worried. } \\
\text { 2. To not be separated from their parents. } \\
\text { 3. To be exposed to limited parental conflict. } \\
\text { 4. To feel happy after the divorce. } \\
\text { 5. To restore their parents' marriage. }\end{array}$ \\
\hline $\begin{array}{l}\text { Needs of } \\
\text { parents }\end{array}$ & $\begin{array}{l}\text { 6. For a healthier post-divorce environment for their } \\
\text { children. } \\
\text { 7. For a more fulfilling life after divorce. } \\
\text { 8. For less conflict after divorce. } \\
\text { 9. To have limited interaction with their ex-partner } \\
\text { after divorce. }\end{array}$ \\
\hline
\end{tabular}

15 South African Divorce Rate (2016) http://www.mydigitallife.co.za/index.php?option= com myblog\&show=the-South-African-divorce-rate.html\&ltemid=29 (accessed 2018-06-14) 1 .

16 McCloud "Top Reasons People Divorce" (2006) http://www.associatedcontent.com/article/ 35097/top_reasons_people_divorce.html?cat= (accessed 2018-06-07) 1.

17 South African Divorce Rate http://www.mydigitallife.co.za/index.php?option=com myblog\&show=the-South-African-divorce-rate.html\&ltemid=29 1 .

18 Ibid.

19 Divorce: Trends and Consequences "Divorcing in Middle and Late Life" (2016) http://medicine.jrank.org/pages/491/Divorce-Trends-Consequences-Divorcing-in-middlelate-life.html (accessed 2018-06-14) 1; Meyer http://divorcesupport.about.com 6; SwerdlowFreed http://expertpages.com/news/child_custody_evaluation_elements.htm. 6. 


\section{$5 \quad$ CHILDREN'S NEEDS POST-DIVORCE}

Children's psychological needs, which are triggered by emotions, are significantly increased during and after a divorce when children are caught in an economic and emotional roller coaster and experience guilt, fear and confusion. $^{20}$ If parents are consciously focused on and sensitive to their children's needs during and after a divorce, they will do a better job of meeting these needs. ${ }^{21}$ It is imperative that children's needs be represented in a parenting plan as this will help children feel heard by the divorcing adults as well as more secure, resulting in the better functioning of children after divorce. ${ }^{22}$ The authors endeavoured to explore the needs of children in divorce processes. The section below focuses on the first identified theme namely, the need of children to feel less worried.

\section{Theme 1: Children's need to feel less worried}

The forensic assessment reports show that, in 22 per cent of the sample, children are worried about where and with whom they are going to stay. Nineteen per cent of the sample indicated that children worry about new arrangements, and 16 per cent worried about finances. Children's worries are mostly about who is going to care for them after divorce and whether there will be enough resources to care for them in their new environment. Overall, it seems that children are confronted with worrying thoughts that can cause anxiety when they are going through a divorce. In the confirmatory emails, one mother remarked:

"When my 9-year-old son started visiting his father, he would always call me on the cell to say hi, literally a minimum of 25 calls a day. I took the calls because I knew it would pass until he was settled as he is a child that often experiences anxieties and feels worried. He would call me first thing in the morning; it could be 5:30am - my phone was always on, I never complained as he needed to know I was there for him. I would always call at $6 \mathrm{pm}$ on the dot every night when he was away, so he felt secure." (File 6)

McGraw $^{23}$ explains that children's worries in a divorce highlight their fear of losing their sense of security and belonging. Children feel insecure and anxious in a changing environment such as divorce, and are worried about provision of their basic needs - such as a house to stay in, food to eat and money to pay for clothes. Acceptance and a sense of belonging are some of children's most significant needs because their self-image is very likely to be in a fragile and formative stage, especially if they are at a young age when

20 Byrnes "Voices of Children in the Legal Process" 2011 17(1) Journal of Family Studies 32 https://doi.org/10.5172/jfs.2011.17.1.44

21 De Jong "Australia's Family Relationship Centres: A Possible Solution to Creating an Accessible and Integrated Family Law System as Envisaged by the South African Law Reform Commission's Issue Paper 31 of 2015" 2017 TSAR 298299.

22 Cleophas and Assim "Child Participation in Family Law Matters Affecting Children in South Africa" 2015 17(2) European Journal of Law Reform 250 https://doi.org/10.5553/EJLR/ 138723702015017002007.

23 McGraw "Children's Needs When Going Through a Divorce" (2009) http://drphil.com/ articles/article/157 (accessed 2018-06-07) 1. 
going through a divorce. ${ }^{24}$ They will try to gain approval because their sense of belonging to the family has been shattered. Children also tend to personalise things and blame themselves..$^{25}$ If their parents are fighting and divorcing, children personalise it and have thoughts such as, "if we did not make so much noise; if we did not need shoes ...". Children need acceptance. They need to know that they are essential and that they are a priority.

Divorce implies numerous changes and children's worries are often valid and relevant. Going through a divorce is stressful for children and may lead to a raised level of anxiety. ${ }^{26}$ Primary school children, in particular and who make up the majority of children in the sample, often worry. They may find it more difficult than older children to go through a divorce since younger children experience raised levels of anxiety and insecurity, and have more limited problem-solving skills. The children's concerns impact on their functioning post-divorce and they may present with unfortunate concerns and developed anxiety. ${ }^{27}$

Children's need to feel less worried during and after a divorce can be addressed if:

- the parenting plan includes strategies to ensure that children maintain a good relationship with both parents and that children are informed about and understand the residential plan and contact that they will have with each parent;

- children are included in the process of drafting a parenting plan, and consideration is given to their worries and they are heard throughout the process of structuring the parenting plan;

- therapeutic support systems for children are included in the plan to address their worries within a therapeutic space; and

- parents understand their commitment to their children post-divorce and that this emotional, physical and financial obligation to the children is explained within the parenting plan.

The next theme identified is children's need not to be separated from their parents. This theme is discussed below.

24 Cleophas and Assim 2015 European Journal of Law Reform 237 https://doi.org/10.5553/EJLR/138723702015017002007; Kelly and Emery "Children's Adjustment Following Divorce: Risk and Resilience Perspectives" 200352 Family Relations 352.

25 Byrnes 2011 Journal of Family Studies 32 https://doi.org/10.5172/jfs.2011.17.1.44; Meyer http://divorcesupport.about.com 8.

26 Altenhofen, Biringen and Mergler "Significant Family Dynamics Related to Post Divorce Adjustment in Parents and Children" 2008 49(1/2) Journal of Divorce \& Remarriage 25; Byrnes 2011 Journal of Family Studies 32 https://doi.org/10.5172/jfs.2011.17.1.44.

27 Amato and Afifi "Feeling Caught Between Parents: Adult Children's Relations With Parents and Subjective Well-Being" 2006 68(1) Journal of Marriage and the Family 222. 


\section{Theme 2: Children's need not to be separated from their parents}

The fear of abandonment emerged strongly as a theme during the document study as children felt a strong need to be with both their parents after divorce. The children indicated a fear of losing either one or both of their parents after divorce. The forensic assessment reports showed that 12 per cent of the children were worried about whether they would be allowed to see and speak to both their parents. Children presented a need for contact with both their parents and the need not to lose either of their parents after divorce. The observation is that children going through a divorce present with fear of abandonment.

Seventy-eight per cent of the children felt scared of losing their parents after divorce whereas twenty-two per cent did not mention fear of losing contact with a parent after divorce. The majority of children experienced the fear of being separated from their parents after divorce. In the confirmatory e-mails, a mother reported the following about her child's need not to lose either parent after divorce:

"My son (four years old) has always been an anxious child and during the divorce process only became more anxious and insecure. He would often ask me whether he would still be able to see his father. When with me, he would miss his father and shout out in an anxious, excited voice 'daddy-daddy' whenever he saw a white bakkie or truck on the road next to us, thinking it was his father. He would speak about the father as though he had just seen him even though he did not have contact with his father for long periods of time." (File 5)

Bennett ${ }^{28}$ explains that the failure of parents to divorce amicably means that children often permanently lose touch with a parent, usually the father. It is also a reality that, owing to the unpleasant experience of divorce and highconflict situation between parents, contact can become complicated and children often end up not seeing one of the parents on a regular basis. It might be as a result of alienating behaviour by one parent where, because of unresolved problems, he or she restricts the children's contact with the other parent. ${ }^{29}$ Some parents try to restrict the relationship that their children have, or might have, with the other parent - sometimes because of lingering anger and pain from the divorce. Alternatively, when communication breaks down, and conflict heats up, one parent might stop adhering to the children's contact schedule and may not allow the children to have time with the other parent. ${ }^{30}$ Children's need to have contact with both parents after divorce is often not fulfilled because of conflict between the parents. The fear of losing

28 Bennett "A Third of Children Lose Touch with Parents After Divorce" (2009) http://women. timesonline.co.uk/tol/life_and_style/women/families/article6917868.ece (accessed 2018-0609) 1.

29 Byrnes 2011 Journal of Family Studies 32 https://doi.org/10.5172/jfs.2011.17.1.44; Kelly and Emery 2003 Family Relations 352.

30 Cale "Challenges of High Conflict Divorce on Children" (2009) http://ezinearticles.com/? Challenges-of-High-Conflict-Divorce-on-Children\&id (accessed 2010-03-26) 1. 
contact with one parent after divorce often becomes a reality, and it leaves the children feeling isolated, lonely and rejected by their parents. ${ }^{31}$

This need of children not to be separated from their parents can be addressed in the parenting plan by providing:

- that both the primary caregiver and the other parent have definite times for visiting during weekends, and holidays, and have structured telephonic and/or video conferencing time;

- $\quad$ for bonding therapy between parents and children to ensure that both parents and children have support after divorce regarding their attachment to each other; and

- for children to attend a post-divorce programme where their fears of separation are addressed as this is a shared concern for children facing their parents' divorce.

The following section will focus on children's need to be exposed to limited parental conflict.

\section{Theme 3: Children's need to be exposed to limited parental conflict}

The battle with conflict emerged as a recurring theme during the analysis of children's divorce experience. Children yearned for their parents to fight less and be more accommodating of each other's feelings. The children in the sample explained that they experience insecurity owing to parental conflict, and that conflict leads to raised levels of stress for the children.

The majority (87 per cent) of children reflected in the forensic assessment reports experienced conflict in their households and wished for the conflict to diminish. Only 13 per cent of children did not refer to conflict in their households. The authors are of the opinion that this absence of conflict may be ascribed to various factors, such as parents who prevent conflict scenarios in front of the children, parents who may have dealt with the problems in a more effective manner, or parents with personality types that do not get involved in volatile, high-conflict situations. In the confirmatory emails, a father provided the following information about the children and conflict:

"The mother and I did our best not to fight in front of the kids. One night when dropping the children off, we argued, and the mother tried to hit me over the head with a vase in front of the kids. It was almost three years ago. My daughter, about six months ago, mentioned this exact event to me in detail and asked why mommy tried to do this. She also asked why we were fighting and it made her sad that we were fighting and that mommy was naughty." (File 1)

Nielsen ${ }^{32}$ suggests that there has been a great deal of publicity about the negative impact of divorce conflict on children. Children exposed to conflict, both in marriage and after divorce, experience significant problems. If

31 Nielsen "Pop Goes the Woozle: Being Misled by Research on Child Custody and Parenting Plans" 201456 Journal of Divorce \& Remarriage 315.

32 Ibid. 
parents continue fighting after divorce, children can become disillusioned and disgusted. When parents' divorce, children hope the fighting will cease so that they can get some peace in their lives. Children often say that they would not mind the divorce so much if their parents could be amicable with each other. ${ }^{33}$ After a divorce, all children want is for their parents to act like grown-ups, leave them in peace, and let them love the other parent. Instead, when conflicts worsen, children are left with many wounds. These wounds and prolonged frustration can include feelings of disillusionment, fear, insecurity, vulnerability, and other similar emotions. ${ }^{34}$ Children develop loyalty conflicts and become afraid to love both their parents or to express their love for one parent in front of the other parent. Many of these children form an alignment with one parent in the hope of feeling less anxious and insecure. This is often the case in alienated children who feel that they cannot have a relationship with both parents because they cannot handle the stress. ${ }^{35}$ Divorced children frequently feel that they have failed or blame themselves when their parents stay in conflict, and they feel even more insecure when they cannot prevent the arguments. ${ }^{36}$

This need to be exposed to limited parental conflict can be addressed in the parenting plan by including:

- strategies to manage post-divorce conflict by stipulating conflict management rules; and

- $\quad$ provision for a parenting coordinator to provide a communication link, foster relationship building, represent the needs of the children, contain destructive conflict, and ease everyone into a healthier, more civilised post-divorce adjustment direction toward growth and recovery.

In the section below, the children's need to feel happy after divorce will be discussed.

\section{Theme 4: Children's need to feel happy after divorce}

In the forensic assessment reports, it emerged that children often mentioned during their assessments that they want to be happy again. Children find the process of divorce difficult, and this consequently creates stress, which can result in depression. ${ }^{37}$ The children's needs reflect that they would like to be able to live a happy and carefree life. In the confirmatory e-mails, a father explained what his daughter conveyed to him about her level of happiness:

33 Cleophas 2015 European Journal of Law Reform 237 https://doi.org/10.5553/EJLR/ 138723702015017002007 ; Kelly and Emery 2003 Family Relations 352.

34 Nielsen 2014 Journal of Divorce \& Remarriage 315.

35 Pretorius "Fathers 4 Justice" (2008) http://www.fathers-4-justice.co.za (accessed 2009-1008) 2.

36 Baris, Coates, Duvall, Garrity, Johnson and LaCrosse Working With High-Conflict Families of Divorce: A Guide for Professionals (2001) 48; Warshak "Social Science and Parenting Plans for Young Children: A Consensus Report" 2014 20(1) Psychology, Public Policy, and Law 46.

37 Baris et al Working With High-Conflict Families of Divorce: A Guide for Professionals 45; Byrnes 2011 Journal of Family Studies 32 https://doi.org/10.5172/jfs.2011.17.1.44. 
"We felt heartbroken when you and mommy used to fight the whole time and especially when mommy moved in with her boyfriend. All that we wanted is for you and mommy to be together again that we can be happy again. Not one of our friends' parents were divorced, and we felt very alone." (File 17)

$\mathrm{McGraw}^{38}$ explains that children of all age groups are affected by divorce in a way that creates unhappiness. Children experience the intense desire to feel happy and not to experience overwhelming negative feelings after divorce. Infants may not understand divorce, but they too can be affected by divorce. Infants may lose their appetite, have an upset stomach and spit up more, which can be an indication of unhappiness. Pre-school children from three to five years of age frequently believe they have caused their parents' divorce. For example, they might think that if they had eaten their dinner or done their chores when told to do so, their father would not have gone away. Pre-schoolers may fear being left alone or abandoned altogether. They may show baby-like behaviour and may become uncooperative, depressed and angry. All of these reactions are an indication that children are experiencing feelings of unhappiness. ${ }^{39}$ School-age children are old enough to understand that they are in pain because of their parents' separation. However, they are too young to understand and control their reactions to this pain. Children may experience grief, embarrassment, resentment, divided loyalty and intense anger, but intense feelings of unhappiness will often accompany these feelings. ${ }^{40}$ Adolescents also experience an overwhelming feeling of unhappiness and may experience anger, fear, loneliness, depression and guilt. $^{2}$

Children's need for happiness after divorce can be addressed in the parenting plan by:

- $\quad$ planning active steps for how the divorcing family will become a newly formed family and how the family will build trust and stable relationships and restore a sense of happiness after the divorce; and

- $\quad$ providing a set of guidelines to improve children's happiness, including age-appropriate guidelines for parents enabling them to support their children - these can include spending quality time with their children; attending a family therapeutic workshop; and ensuring that an open and supportive relationship is promoted after divorce so that children feel emotionally supported and can voice their feelings.

Discussed next, as reflected in the forensic assessment reports, is children's need to restore their parents' marriage.

\section{Theme 5: Children's need to restore their parents' marriage}

A theme that emerged in analysing the forensic assessment reports is children's desire for their parents to remain in the marriage. It was found that

38 McGraw http://drphil.com/articles/ article/157 1.

39 De Jong 2017 TSAR 300.

40 Kelly and Emery 2003 Family Relations 352; Warshak 2014 Psychology, Public Policy, and Law 46.

41 Nielsen 2014 Journal of Divorce \& Remarriage 315. 
often children would express their hope that their parents would change their minds and that they would reconsider the divorce. It seems that children want the family unit to stay intact and often fantasise that their family will not go through a divorce but that something will happen that will make their parents change their minds and stay married.

Eighty-four per cent, the majority of children, expressed the hope that their parents would stay married and not get a divorce. Only 16 per cent of the children indicated that it would be better for their parents to get a divorce. In the confirmatory e-mails received, a mother stated the following regarding the desire children may have for their parents to stay together:

"In the last six months before the divorce, my son (5yrs) often began to open up more and say he wanted me to stay married to his dad. He wanted me to go with him on visits when seeing his dad. He would create a scenario for his dad and me to talk to each other. He often asked if I loved his dad - when I said no, he looked for a little bit of hope and said 'maybe a little bit?"' (File 12)

Haugen ${ }^{42}$ reports that even years after a divorce, children may still fantasise that their parents will reunite. It is especially the case with young children as they often want their family back and do not fully understand the divorce. Divorce comprises a series of transitions and stages for both adults and children. These stages are similar to the stages Elisabeth Kubler-Ross described for patients with terminal illnesses: denial, anger, bargaining, depression, and acceptance. During a divorce, children experience these stages quite differently from adults. In the denial stage, the children fail to believe that their parents, the adults who provide them with a safe home, shelter and food, could ever part. During this time, the children reassure themselves that their parents will stay together, and if they are already separated, that they will soon reunite. This reunion fantasy often persists for years. Anger, the second stage, follows denial. Children can be furious at their parents for not trying harder to stay together, for permitting the divorce to happen, and for ruining their lives. Acting-out behaviour often accompanies the anger. ${ }^{43}$

According to Amato and $\mathrm{Afifi}^{44}$ children enter the bargaining stage by trying to undo the damage by changing their actions. Children think if they get better grades, perform their daily chores without complaining, and quit fighting with their siblings, the absent parent will return home to stay. In the depression stage, there is a pervasive sadness that permeates every aspect of the child's life. Children are sad and tired every day at school and at home. Children who reach this stage and who appear to be driven to succeed in some way must be kept an eye on, as they might be suffering the most. Finally, acceptance occurs when the children have gained the emotional experience and distance to see that perhaps the divorce was for the best and that their parents are happier living apart than they would have been living together. This stage usually occurs only in older children or maybe in some young adults.

42 Haugen "Caring Children: Exploring Care in Post-Divorce Families" 2007 55(4) The Sociological Review 34.

43 Altenhofen, Biringen and Mergler 2008 Journal of Divorce \& Remarriage 25; Warshak 2014 Psychology, Public Policy, and Law 46.

44 Amato and Afifi 2006 Journal of Marriage and the Family 230. 
The children's need for restoration of the parents' marriage can be addressed in the parenting plan by:

- including methods for both parents and children to put in place necessary boundaries to prevent confusion for the children;

- addressing sub-system boundary dysfunction by setting clear boundaries for children and parents to ensure that children can healthily process their parent's divorce; and

- $\quad$ providing for divorce therapy for families where boundaries seem to be intermeshed and children feel uncertain about the reality of their parents' divorce - so as to set clear boundaries for the parents, and promote children's understanding of the realities of the divorce and the new phase their family will be moving into as separate units.

It is critical that a parenting plan include the needs of children with the aim of empowering them, and for the children to feel that they have been heard in the process of drafting the parenting plan.

The section to follow focuses on the needs of parents.

\section{THE NEEDS OF THE PARENTS AFTER DIVORCE}

Bailey ${ }^{45}$ explains that divorce is one of the most stressful events that an individual may experience. Some stress is inevitable, given the resulting transformations in marriage and family relationships, shifts in daily routines, roles, activities, and social relationships. ${ }^{46}$ There may be challenges to the way that people view themselves, with some reporting a sense of being offbalance and adrift, and no longer sure of who they are and what they want. Even those who are relieved to be free of an unhappy marriage may be apprehensive about the future and the many stressors they are encountering. Many parents have to re-evaluate their needs after divorce. ${ }^{47}$ Professionals should consider the specific needs of the parents as this may give them insight into the divorcing family when they are structuring parenting plans. The following themes presented themselves as the needs of parents after divorce: the need to provide children with a healthier environment and reduce exposure to unpleasant experiences; the need to start a new and more fulfilling life; the need to reduce conflict; and the need to have limited contact and communication with the ex-partner. Below is a discussion of these themes.

45 Bailey "Co-Parenting After Divorce" 20163 MontGuide MT200111HR 1.

46 Nielsen 2014 Journal of Divorce \& Remarriage 316; Warshak 2014 Psychology, Public Policy, and Law 46.

47 Alba-Fisch "Collaborative Divorce: An Effort to Reduce the Damage of Divorce" 2016 72(5) Journal of Clinical Psychology: In Session 444; Haugen 2007 The Sociological Review 35. 


\section{Theme 6: Parents' need for a healthier post- divorce environment for their children}

In the forensic assessment reports, parents signified a desire for their children to live a more functional life after divorce, similar to the need expressed by the children for a more functional life after the divorce. Parents believe that, after a divorce, they should provide their children with a changed environment that is more conducive to delivering healthier and more functional children. In the confirmatory e-mails received from the parents, a father said the following as to the need to live a healthier life and in a more pleasant environment after divorce:

"A divorce is undoubtedly a gut-wrenching experience. It draws every last bit of life out of you and drains you emotionally. In my experience, your children are the only ones that you offer unconditional love. Having said this, you know your children have suffered, and you want to move forward offering your children a much healthier and emotionally balanced environment. You want to protect them from all of the negative experiences you have and guard them against all of the ugliness involved." (File 18)

Nielsen ${ }^{48}$ and Warshak ${ }^{49}$ support the result and specify that life after divorce can lead to a healthier, happier and more functional situation for both parents and children. However, this depends on the commitment of the parents to create a healthy and functional altered family unit after divorce. By identifying this particular need, the parents reveal that they are committed to having their children live happier lives after divorce. ${ }^{50}$ Unfortunately, this promise is often not met after divorce as many parents continue to live in high-conflict situations with each other. It affects the happiness of their children and works against the standard of acting in the best interests of the child. ${ }^{51}$

The parents' need for a healthier post-divorce environment can be addressed in the parenting plan by including:

- restorative practices for the divorcing family to ensure optimal functioning after the divorce (such as family therapy, attending support groups, family workshops, and bonding therapy); and

- $\quad$ ractical submissions stipulating that parents should take responsibility for, and care for the children (rather than leaving them for extended periods of time with a caregiver) thus shifting parental responsibility of care onto him/her; personally engage with their children and attend functions of their children; attend sports and cultural activities; and create a happy and secure environment after the divorce.

The next section will focus on the parents' need to start afresh and live a more fulfilling life after divorce.

48 Nielsen 2014 Journal of Divorce \& Remarriage 316.

49 Warshak 2014 Psychology, Public Policy, and Law 46.

50 Alba-Fisch 2016 Journal of Clinical Psychology: In Session 444; Bailey 2016 MontGuide MT200111HR 1.

51 Meyer http://divorcesupport.about.com 1. 


\section{Theme 7: Parents' need for a more fulfilling life after divorce}

In analysing the forensic assessment reports, the parents' need to start a new and more fulfilling life after divorce emerged. Parents experienced their married life to be empty and they felt that there was more to life than what they had experienced in their marital life. Parents referred to seeking a new life after divorce where they could reach their potential and find themselves, who they are, and what they want.

Eighty per cent of the sample hoped to have a chance for a new and more fulfilling life after divorce, an indicator that parents have a desire to change their lives after divorce, with the intent to live a more rewarding, functional and positive life. In the confirmatory e-mails received from the parents, a mother mentioned the following about having a new and more fulfilling life after divorce:

"I had a horrific past with my ex-husband as he is a terrible person. I would like to move on, be confident, date and then eventually remarry. I do not ever want to be connected to him again as he suppressed my individuality to the point where I did not know who I am anymore. He has only brought pain and suffering and disappointment, chaos, rejection to both my son and I. I need to break free, I am ready to fly and be the spirited and lively person I used to be 15 years ago." (File 16$)$

Dimeck ${ }^{52}$ explains that divorce is one of the most traumatic experiences a person can go through but that this does not mean the potential for a happy and more fulfilling life has ended. A divorce can leave a parent wholly worn out and drained of the desire to go on with life but it is not the end of everything. ${ }^{53}$ A parent must realise that it is the end of one period or chapter in life and that there is an opportunity for a new beginning. Parents should accept their current situation, and build their life into what they want it to be after divorce. Haugen ${ }^{54}$ explains that, when a divorce occurs, parents should seek to grieve the loss of the marriage and to successfully go on with their lives and the lives of their children, and they should focus on the wish that life after divorce be more fulfilling - not only for themselves but also for their children. Parents have every right to go on with their lives after divorce: the expectation and hope is that there will be a new relationship, which will provide new love, caring, and understanding for both parent and children. ${ }^{55}$

The need for parents to have a more fulfilling life after divorce can be addressed in the parenting plan by:

- including stipulations that provide for parents to take responsibility for their children while including rules of engagement about new partners, specifying boundaries as to new partners and responsibilities relating to

52 Dimeck "Ten Steps to Help You on Your Way Back to a Fulfilling Life After Your Divorce" (2010) http://www.lifeafterdivorce.net/finding_happiness.html (accessed 2018-04-12) 1.

53 Alba-Fisch 2016 Journal of Clinical Psychology: In Session 444; Bailey 2016 MontGuide MT200111HR 1.

54 Haugen 2007 The Sociological Review 12.

55 Altenhofen, Biringen and Mergler 2008 Journal of Divorce \& Remarriage 25; Warshak 2014 Psychology, Public Policy, and Law 46. 
the children - for example, specifications as to new partners and discipline of the children;

- $\quad$ including provision that parents should receive emotional support and therapeutic services - for example, mental health professionals should be appointed to support parents with their new journey to ensure that the lived experience is more positive and functional; and

- $\quad$ providing for enrolment in a care and well-being programme to guide parents on how to live a more fulfilled and positive life.

The section below focuses on parents' need to reduce conflict for their own sake and that of their children.

\section{Theme 8: Parents' need for less conflict after divorce}

In the forensic assessment reports, it was found that parents experienced their marital relationship as a relationship filled with constant conflict. Conflict was mentioned throughout the reports and parents identified it as a highly problematic issue for their own and their children's functioning.

Most divorcing families exhibit symptoms of high conflict. Eighty-five per cent of parents expressed a need to have less conflict in their lives and a preference not to be exposed to conflict as the high-conflict situation had created dysfunction for themselves and their children. In the confirmatory emails received from parents to validate the analysed information, a father stated the following about the need to reduce conflict after divorce:

"I do all I can to protect the children from the emotions I feel and to protect them from fighting and the conflict that they have been exposed to in our marriage. No matter how much I feel their mom is the person in the wrong, I have to swallow my pride and take into consideration that all I am doing if I

bad mouth their mom, is I am letting my children carry the guilt and emotions.

Sometimes it is tough, but I have to look at the bigger picture." (File 18)

Duchen and Dennill ${ }^{56}$ explain that conflict is not an on-and-off phenomenon and that it is a typical aspect of most relationships. Conflict can be contextualised with reference to its severity. It comes from the push and pulls of wills and personal agendas. It comes from old wounds and memories, from fear and loneliness, and from a loss of identity and dreams for the future. Conflict can even feel very self-protective and safe. ${ }^{57}$ When there is merely a disagreement, conflict is not problematic. However, as coercion begins and resistance escalates, the tug-of-war begins to develop. This tug-of-war leads to hostility and then severe conflict. At its worst, there is active warfare, which involves sabotage, spying, positioning, threats and attacks. While these are terms of war, they occur between divorcing and divorced parents as well. ${ }^{58}$ Due to the cruelty that conflict brings to family

56 Duchen and Dennill Post-Divorce Conflict: Dealing Effectively With Conflict Through Parenting Plans Paper presented at the Fifth Annual National Conference on Dealing with Children and Divorce (September 2005) 3.

57 Kelly and Emery 2003 Family Relations 352; Warshak 2014 Psychology, Public Policy, and Law 46.

58 Bailey 2016 MontGuide MT200111HR 1; Kelly and Emery 2003 Family Relations 352. 
functioning, a plan needs to be prepared to prevent parents and children from being exposed to new post-divorce conflict. In the long run, this is the aim of the parenting plan. ${ }^{5}$

This need for less conflict after divorce can be addressed in the parenting plan by:

- providing conflict reduction mechanisms as solutions for families that engage in contentious, highly adversarial, and prolonged conflict;

- including post-divorce intervention to provide the knowledge and skills needed to manage high-conflict situations, recognising that conflict can be contained by constructing and engaging a network of professionals; and

- appointing professionals with specialised roles such as a parent coordinator, special Master, and guardian ad litem in the parenting plan to ensure that conflict is effectively managed post-divorce.

The section below focuses on the parents' need to have limited communication and contact with their ex-partner after divorce.

\title{
64 Theme 9: Parents' need to have limited interaction with their ex-partner post-divorce
}

According to the research results, after divorce, parents would like to carry on with their life and attempt to focus on the future, not the past. In the reports, parents wanted less contact with, and only wanted to communicate with, their ex-partner when and if needed. The majority (63 per cent) of parents said that they did not want to communicate nor have contact with their ex-partners after divorce. Twenty-eight per cent of parents indicated that they would prefer to talk to and see their ex-partner only when they had to discuss something about the children. Ten per cent of parents still have an amicable relationship. However, this is not the norm as reflected in postdivorce relationships. In confirmatory e-mails received from the parents, a mother shared the following about her need to have limited contact and communication with her ex-husband:

\begin{abstract}
"I would like to have no contact. I tried in the past to have an amicable and friendly relationship with him, but he twists around the truth and communication always ends up in a nasty situation. I believe he plays offensive mind games, he lies, and I feel that as little contact with him as possible makes my life much more manageable. I am not interested in any relationship with him. It is not easy for the children, but with contact comes conflict that always ends in a continuous stressful situation that is a very negative experience for the children." (File 13)
\end{abstract}

Elder $^{60}$ found that communication and contact after divorce can be difficult for most couples as they would like to move on with their lives and do not necessarily want to have contact with their ex-partner. A breakdown of communication is often a deciding factor in divorce. After a divorce, overall

59 Baris et al Working With High-Conflict Families of Divorce: A Guide for Professionals 45; Haugen 2007 The Sociological Review 21.

60 Elder "Communication and Co-Parenting after Divorce" (2010) http://www.totaldivorce.com/ news/articles/children/co-parenting-after-divorce.aspx (accessed 2018-04-13) 1. 
levels of physical contact, conflict and emotional attachment between spouses typically diminish rapidly. Ex-spouses' ability to communicate with each other after divorce typically does not improve. However, if there are children involved, parents will need to have some form of communication with each other. ${ }^{61}$ Contact is not necessarily needed, but communication will have to take place in some form. Some parents would like to have contact, although not always for the right reasons. ${ }^{62}$ Effective and limited communication is healthy after divorce; it is thus imperative to set boundaries regarding contact and communication between parties. Limited contact and communication may be a method to limit further anxiety for the divorcing family. ${ }^{63}$

This need for limited interaction after divorce can be addressed in the parenting plan by:

- $\quad$ including an agreement of understanding that both parents still have the responsibility to care for their children and that this will inevitably lead to the parents having contact - healthy boundaries and methods of engagement can be included to ensure that both parents understand their new roles after divorce and specify new ways of engaging each other;

- $\quad$ including an imperative that parents obtain counselling and assistance to develop insight into the changed parental relationship dynamics after divorce, and to specify a working relationship between the parents, especially with parents who find it difficult to engage with each other; and

- $\quad$ providing for continuous mediation to structure all communication and contact between parents after divorce.

For a representative, functional and successful parenting plan, it is vital that it reflect the parents' needs.

\section{CONCLUSION}

After a divorce, children and parents share the need to start a new life, and for a healthier environment with reduced conflict. In the research study, both parents and children indicated a need to have fewer overall stressors and to experience feelings of happiness. Conflicting needs are found where children do not want to lose a parent, but parents wish to have limited contact with the other parent. Children ultimately would like their parents to stay married, whereas ideally parents would not have contact with the other parent. During the process of drafting a parenting plan, it remains challenging to meet and accommodate all family members' needs because of emerging conflicting needs. It is critical that parenting plans be representative of the divorcing family's needs overall, and that they strive to meet the best-interests-of-the-child standard. It is crucial that a parenting plan represents the parents and the children's needs respectively and that the plan promotes the best interests of the children and empowers the

\footnotetext{
Bailey 2016 MontGuide MT200111HR 1.

Amato and Afifi 2006 Journal of Marriage and the Family 227.

3 De Jong 2017 TSAR 167; Kelly and Emery 2003 Family Relations 352.
} 
parents with a well-considered post-divorce vision. To optimise family wellbeing, it is essential that parenting plans be representative of the family's needs, and this can only materialise when professionals understand the needs of families. The next section provides conclusions and recommendations about the findings in this article.

\section{RECOMMENDATIONS ON HOW PARENTS' AND CHILDREN'S NEEDS SHOULD BE ADDRESSED IN A PARENTING PLAN}

- A post-divorce adjustment programme should be developed for children. It will be important that such a programme be age-appropriate and culture-sensitive to equip children with the necessary skills.

- The above-mentioned programme should form part of the services rendered by the Family Advocate Offices or mandated NGOs.

- To serve the best interests of the child, all children should have access to therapeutic services and this should be written into the parenting plan.

- An educational programme for divorcing parents should be developed to equip them with the necessary tools to prevent adjustment problems for their children.

- It should be compulsory for both parents to attend an educational programme, and it should be written into the parenting plan.

\section{SUMMARY}

The authors approached the article from the position of divorcing families having needs that have consequences for their lives after divorce. We have described different needs from the perspective of children and parents respectively and made recommendations on how professionals can give voice to these needs when structuring a parenting plan. 